\title{
ОНЕЙРИЧНИЙ ПРОСТІР ХУДОЖНЬОЇ ПРОЗИ ВОЛОДИМИРА ДАНИЛЕНКА: СНИ І СНОВИДІННЯ ЯК КУЛЬТУРНИЙ ТЕКСТ
}

\author{
Осьмак Н. Д., Бикова Т. В.
}

\section{ВСТУП}

Однією 3 найтаємничіших та найзагадковіших форм позасвідомого життя людини $є$ сон. Упродовж багатьох тисячоліть людство постійно цікавилося тлумаченням сновидінь, вірило в їхній пророчий зміст. Сутність сновидінь і сну ставала об'єктом наукового дослідження філософів, культурологів, психологів, лікарів, літературознавців, етнологів, фольклористів тощо.

Важливим моментом у дослідженні понять «сон» і «сновидіння» $\epsilon$ з'ясування їхніх спільних та відмінних рис. Так, термін «сон» варто вживати у двох значеннях: 1) як ознаку фізіологічної потреби, яка визначає природний перехід від стану усвідомленої свідомості до відходу у стан засинання i, навпаки, у стан усвідомлення свого «я»моменту пробудження; 2) поняття «сон» може бути синонімом до поняття «сновидіння». «Сновидіння», у свою чергу, - це серія образів, подій, запахів, які уявляються людині під час сну, це «психічна діяльність під час сну, - діяльність, близька до діяльності нашої психіки у стані неспання і все-таки вкрай відмінна від неї» ${ }^{1}$. Тобто поняття співвідносяться одне з одним як зміст і форма в художньому творі, «сон» має ширше значення, натомість сновидіння $€$ «душевним життям під час сну» ${ }^{2}$, а сон становить собою фізіологічний стан, коли людина втрачає інтерес до подій зовнішнього світу.

У міфології різних народів завжди було божество, яке відповідало за сон. Так, у грецькій це Гіпнос - персоніфікований образ сну, син Ночі та Мороку, брат бога смерті Танатоса; Морфей - бог, що формує сновидіння. Крім того, ще є Фобетор (бог сну у вигляді тварин та людей) i Онейрос (бог віщих i неправдивих сновидь) та інші. У слов'янській міфології божество сну уособлювали нічниці та Мара. Наші пращури вірили, що коли душа переміщується в онейричний простір, то кожного разу залишає тіло, але повертається 3 першими

\footnotetext{
1 Фрейд 3. Введение в психоанализ : лекции. Санкт-Петербург, 1999. URL: http://krotov.info/library/21_f/re/freyd_2.html.

2 Фрейд 3. Введение в психоанализ : лекции. Санкт-Петербург, 1999. URL: http://krotov.info/library/21_f/re/freyd_2.html
} 
променями сонця. Цей процес ми називаємо сном. Якщо ж душа не повертається, то наступає вічний сон - смерть.

\section{1. Науково-теоретичні аспекти дослідження проблеми «сон» у художній літературі}

Наукове вивчення сновидінь розпочалося із праць «Тлумачення сновидінь» (1900р.) 3. Фройда, «Таємниця сну» (1906 р.) Д. Бігелоу, «Сон та міф. Нарис народної психології» (1912р.) К. Абрахама, «Іконостас» (1912 р.) П. Флоренського, «Театр як сновидіння» (1912 р.) М. Волошина, «Архетип і символ» (1912 р.) К.Г. Юнга Набагато ширше ці проблеми опрацьовано в численних працях із філософії, психології та культурології К. Абрахама, А. Адлера, Г. Башляра, О. Вейна, Ж. леГоффа, М. Еліаде, Ю. Лотмана, Х. Кодуелла, Е. Тайлора, П. Флоренського, 3. Фройда, Е. Фромма, С. Цвейга й інших. 3 50-х рр. $\mathrm{XX}$ ст. дослідження процесу сну залишаються актуальними. Механізм сну вивчає спеціальна дисципліна із психології - онейрологія, яка грунтується на твердженнях, що у сні реалізуються підсвідомі бажання (3. Фройд), сон - символічний (К.Г. Юнг), образи снів - це люди, які чимось нас уражають (Л. Шепперд). Окрім спеціальних праць природничо-наукового та психофізіологічного характеру, існують зацікавлення проблемами сну вченими гуманітарного профілю в напрямах, пов'язаних із взаємодією сну 3 релігією, історією, мистецтвом, філософією та художньою літературою.

Літературна традиція використання сну і сновидінь відома ще 3 давніх часів із біблійних і античних сюжетів. Так, у Книзі Буття зазначається: «Тоді Господь Бог навів глибокий сон на чоловіка, і коли він засну, узяв одне з його ребер і затулив те місце тілом» ${ }^{3}$, а в одному 3 уривків «Іліади» говориться про сон Агамемнона. Ідеться насамперед про онейричну літературу, «сенс якої виражається або завдяки мотиву сновидіння, або через особливості зумовленої ним композиції» ${ }^{4}$.

Науковці, які досліджували проблеми сну, пропонували ввести в обіг відповідну термінологію, наприклад «онейричний хронотоп», або «онейротоп», щоб «перебороти термінологічний вакуум» у філологічних дослідженнях сновидінь. Т. Теперик відзначає: «Онейротоп охоплює весь художній контекст, пов'язаний із зображенням сновидіння, разом з усім комплексом використовуваних

${ }^{3}$ Святе Письмо Старого та Нового завіту. Повний переклад, здійснений за оригінальними єврейськими, арамійськими та грецькими текстами. URL: https://bible-lessons.in.ua/bible/old/book01/g102.html.

4 Літературознавча енциклопедія : у 2-х т. / авт.-укл. Ю. Ковалів. Київ : ВЦ «Академія», 2007. Т. 2. С. 153. 
засобів»5. Водночас дослідниця робить висновок, що онейротоп $€$ «одним 3 елементів більш широкого «парасолькового» поняття

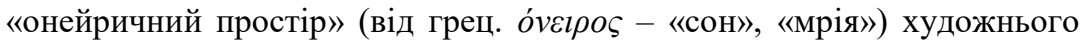
дискурсу» ${ }^{6}$. В. Савельєва уживує поняття «онейричний текст», водночас бере до уваги текстоцентричний підхід. У iï розумінні «онейричний текст» - «вербальне відтворення сновидіння, сноподібного або зміненого стану свідомості (марення, стрес, мрія, галюцинація, безсоння) персонажа або автора художнього твору» ${ }^{7}$.

Саме тому сновидіння завдяки символічній природі сну ми можемо сприймати як певний культурний текст, що існує у знаковій, символічній формах. Нині існує обмаль наукових досліджень, присвячених вивченню природи снів, відображених у літературних творах із позиції філософії, релігієзнавства, культурології, естетики та психології.

У кожній національній літературі $є$ письменники, які звертаються до проблем сновидінь, розкривають внутрішнє життя героїв засобами сну, акцентують увагу на важливості цього елемента життя людини в іiі розумінні світу. Через сон у літературних творах, осягнення потаємного, автори розкривають і вмотивовують учинки, характери героїв, вкладають символічний зміст, тлумачать майбутні події у творі, адже зображення позасвідомих станів сприймається «як своєрідна мізансцена, що промовляє до читача у формі невиразних знаків» ${ }^{8}$.

У художніх творах мотиви сновидінь класифіковані науковцями за різними категоріями. За основу вони беруть розуміння, що сновидіння становлять основу сприйняття внутрішнього несвідомого в персонажа. Якщо у творі змальовані сновидіння, вони несуть подвійне смислове навантаження, $з$ одного боку, вони розкривають найпотаємніші думки героїв, їхні світоглядні переконання, емоційний стан, а 3 іншого боку, дають можливість побачити результат того, що може трапитися, якщо людина не враховує всіх нюансів своєї поведінки. У художньому тексті сновидіння сприймаються як сюжетотворчий та структуротворчий елемент. Елементами характеристики сновидінь у творах $€$ «можливість цілковитої свободи до моменту пробудження; естетико-філософська

5 Теперик Т. О поэтике литературных сновидений. Русская словесность. 2007. № 3. C. 15.

6 Теперик Т. О поэтике литературных сновидений. Русская словесность. 2007. № 3. C. 15.

${ }^{7}$ Савельева В. Художественная гиппология и онейропоэтика русских писателей : монография. Алма-Ата, 2013. С. 21.

8 Бовсунівська Т. Достовірність онірокритики та ï постмодерні стратегії. Сучасні літературознавчі студї : збірник наукових праць. Київ, 2004. Вип. I : Онірична парадигма світової літератури. С. 15. 
мотивація, своєрідні коментарі до життя (головний акцент: життя не таке просте); можливість подорожі в часі; змога побачити майбутне людства - створення утопії чи антиутопії; можливість усвідомити всі свої антигуманні вчинки і таким чином покаятися» ${ }^{9}$.

У світовому літературознавстві було зроблено чимало спроб класифікувати сновидіння, які використовують письменники в текстах. Дослідники вибирають різні критерії за основу поділу онейросфери. Так, психологічний критерій став основним під час поділу сновидінь, використаних у художніх творах Ю. Григорчук, що виділяє «концептуальні - сни, які відбивають авторське бачення життя та реалізуються крізь призму образів-символів і архетипів; компенсаційні - сни, які виявляють психологічні процеси, в основі яких лежать нездійснені бажання; профетичні - «віщі», або «пророчі», сни i видіння, які слугують засобом створення акаузальних ситуацій (поетики чуда)» ${ }^{10}$.

Інший критерій поділу застосовує О. Волик, яка групує їx відповідно до функцій, які вони виконують у творах: «1) характерологічні сновидіння (розкривають справжнє «я» героя, приховані риси характеру); 2) проскопічні сновидіння (передбачають майбутнє героя або навіть усього людства, часто в алегоричній формі); 3 ) кризові сновидіння (кардинально змінюють життя людини, іiі погляд на повсякденність)» ${ }^{11}$.

Близьким за класифікацією сновидінь до О. Волик є типологічний поділ сновидінь, запропонований І. Фазіуліною: «1) сни-передчуття, які емоційно готують події, що відбуваються в житті героїв і мають для них вирішальні наслідки; 2) сон як засіб психологічного аналізу (кризові сновидіння)» ${ }^{12}$.

Найбільш повну характеристику різним видам сну надала у своєму дослідженні Н. Фенько. Основна ознака, за якою відбувається поділ сновидінь, - це їхній характер впливу на психологію літературного персонажа: «сни-потрясіння (які включають сни психологічного

${ }^{9}$ Руднев В. Культура и сон. Даугава. 1990. № 3. С. 122.

10 Григорчук Ю. Сновидіння як «семіотичне вікно» містичного : своєрідність оніропростору повістей Віри Вовк. Spheres of Culture. Lublin, 2012. Vol. II. C. $168-177$.

11 Волик Е. Язык и функции сновидений в словесном искусстве. Вісник Харківської державної академії дизайну $і$ мистецтв. Серія «Мистецтвознавство. Архітектура». 2007. № 3. С. 163.

12 Фазиулина И. Сон и сновидение в раннем творчестве Ф.М. Достоевского : поэтика и онтология : дис. ... канд. филол. наук: 10.01.01. Ижевск, 2005. С. 18. 
конфлікту (сон-катарсис, сон-каяття) та пророчі сни), і сни-заспокоєння (сни-мрії, сни-спогади, сон-архетип)» ${ }^{13}$.

Запропоновані класифікації онейросфери, на нашу думку, $\epsilon$ взаємодоповнюючими, обрати одну, без урахування позицій інших, неможливо: вони сприяють більш глибокому розумінню ідейнотематичного навантаження художнього тексту. Вони $\epsilon$ ціннісним критерієм у розкритті і характеристиці внутрішнього світу героїв творів, умотивуванням і поясненням їхніх учинків, емоцій і взаємодії із зовнішнім світом.

У світовій літературі Ш. Бодлер, Г. Гессе, М. Гоголь, Н. Готорн, Е.Т.А. Гофман, С. Колрідж, Дж. Лондон, Т. Манн, А. Міцкевич, Е. По, О. Пушкін, Ю. Словацький, Дж. Фаулз, Г. Флобер, К. Чапек, українській T. Шевченко, Панас Мирний, I. Нечуй-Левицький, Леся Українка, I. Франко, Л. Костенко, В. Даниленко й інші, використовували як художню форму відображення дійсності сновидіння та сон. Письменники часто наголошували на значенні в ідейному навантаженні твору сну, уживали ці поняття в заголовках: «Сон в літню ніч» В. Шекспіра, «Життя $є$ сон» П. Кальдерона де ля Барки, «Сон і життя» Г. Гейне, «Сон» Г. Байрона, «Сон Алонсо Кохана» Х.Л. Борхеса, «Сон» («На панщині пшеницю жала $<\ldots>»)$, «Сон» («Гори мої високії <...>») та «Сон» («У всякого своя доля $<\ldots>$ > Т. Шевченка, «Сон української ночі» В. Пачовського, «Заквітчаний сон» Г. Косинки й інші.

3 огляду на великий масив творів художньої літератури, де письменники використовують мотиви й образи сну та сновидінь, актуальним залишається дослідження поетики сну у творах, зіставлення образів сновидінь у літературному джерелі з реальністю, психологічним станом героя. Об'єктом дослідження стають твори не тільки попередніх епох, а й сучасних авторів, які вміло поєднують традиції світової літератури з новими віяннями та напрямами, створюють полісинтетичне джерело для вивчення й інтерпретації авторського світогляду. Важливим $\epsilon$ визначення структурно-семантичних, стильових, функціональних особливостей та зображально-виражальних можливостей сновидійного наративу у творах.

\section{2. «Онейричність» як провідна особливість індивідуального стилю у прозі Володимира Даниленка}

Сучасний український літературний процес відбувається в тандемі зі світовими тенденціями. Українські автори - Ю. Андрухович, С. Жадан,

${ }^{13}$ Фенько Н. Естетичні функції картин сновидінь у художніх творах українських письменників другої половини XIX-XX ст. : автореф. дис. ... канд. філ. наук: 10.01.01. Дніпропетровськ, 1999. С. 7-8. 
Ю. Винничук, О. Забужко, А. Кокотюха, В. Шевчук та інші займаються новаторськими пошуками й експериментами, спрямованими на утвердження в сучасній українській прозі непересічного представника, що моделює різні жанрові структури: авантюрний детектив, біографічний роман, роман-кросворд, роман-містифікацію, роман у новелах, у яких поєднуються елементи поетики бароко, готики, реалізму, неомодернізму, постмодернізму тощо. Проза В. Даниленка як цілісне і якісне художнє явище стоїть осторонь від решти представників української літератури. Його творчості притаманні такі риси, як художній поліфонізм, філософсько-інтелектуальне спрямування та психологізм.

Художня проза В. Даниленка мистецьки продовжує традиції української художньої психологічної літератури. «Для стильової манери його творів не $\epsilon$ характерною гра із чужими словами, цитування, намагання епатувати читача нецензурною лексикою чи описом насильницьких сцен» ${ }^{14}$. Безпосередньо літератор неодноразово наголошував у пресі наявність прийому психологізму у його творчості як провідного: «З моєї пам’яті легко стирається абстрактна інформація, яка не стосується пережитого досвіду, але добре зберігаються психічні реакції на реальні події <..> Така пам'ять добре пристосована до написання психологічної прози» ${ }^{15}$.

Складовою частиною сюжетно-композиційної будови його творів $\epsilon$ сновидіння, саме тому провідною рисою його індивідуального стилю $\epsilon$ онейричність. Використання онейротопів як засобу, що «не тільки надає психологічну характеристику сновидцеві, а й дозволяє зруйнувати межі часу i зазирнути в майбутнє» ${ }^{16}$, уважається наративною стратегією В. Даниленка. Тлумачення сновидінь у творах митця $€$ цілком природним i зрозумілим для читача, він 3 легкістю розуміє символічний зміст, закладений у сні. Крім того, «наратор іноді не залишає читачеві простору для фантазії й інтерпретує їх самостійно, що є виявом авторської інтенції» ${ }^{17}$.

14 Лаврусенко М. Жанрово-стильові особливості оповідання Володимира Даниленка «Черемхова віхола». Вісник Луганського національного університету імені Тараса Шевченка. 2012. № 3.Ч. II. С. 171.

15 Кононенко С. Володимир Даниленко i література із пробірки. URL: http://www.umoloda.kiev.ua/number /810/164/29496/.

${ }^{16}$ Вещикова О. Семіотика містичного в оповіданні В. Даниленка «Дегустація в будинку 3 химерами». Сучасна україністика. Проблеми мови, літератури та культури. Оломоуць, 2014. С. 271.

17 Вещикова О. Пролептичний потенціал сновидіння у структурі художнього наративу (романи В. Даниленка «Кохання в стилі бароко» i В. Шевчука «Кросворд»). Наукові праці Чорноморського державного університету імені Петра Могили комплексу «Києво-Могилянська академія». Серія «Філологія. Літературознавство». Миколаїв, 2015. Т. 259. Вип. 247. С. 16. 
Літературознавці не залишили поза увагою наявні риси онейричності творчості В. Даниленка: він «здебільшого «нічний» письменник, який зазирає в темні глибини життя і знаходить потаємні пружини, що рухають світом. У нього добре розвинуте почуття ілюзорності земного життя, таємничих і містичних сил. Місто Даниленка - вмістилище солодкого гріха. У ньому панує ніч, темна, як безодня Всесвіту» ${ }^{18}$. Якщо проаналізувати світопростір героїв В. Даниленка, то, на думку Т. Николюк, вони глибоко залежні від сну, вірять у його містичність, здатність передбачити майбутнє. Ці герої $є$ досить творчими особистостями, наприклад, музикант Євген Луньо (повість «Сонечко моє, чорне й волохате»: «Він - піаніст, музикант не від світу цього», «<..> в нього просторовий ідіотизм, він не запам'ятовує імена людей і ніколи нічого не чує» ${ }^{19}$. Маємо досить цікаву характеристику, яка «дається творчій особистості, людині, яка вирізняється з-поміж інших ставленням до речей, людей, оригінальністю світогляду та безпорадністю в побуті» ${ }^{20}$.

За допомогою герменевтичного підходу в поєднанні із психологічним, міфологічним та структурно-семіотичним методами схарактеризуємо онейричність як провідну рису індивідуального стилю у прозі В. Даниленка на прикладі окремих його творів. Так, у назві роману «Кохання в стилі бароко» відчувається алюзія до назви твору П. Кальдерона де ла Барка «Життя - це сон». Інтертекстуальність романукросворда посилюється твердженням Ж. Лакана: «Сон нагадує гру в шараду, у якій глядачам пропонується в німій сцені вгадати значення потрібного слова. < ..> I процес розгадування, і кохання чоловіка й жінки, i минуле, і сучасне в романі нагадують дивний сон. Зрештою, хіба наше життя не дивний сон, який зникає в момент пробудження?» ${ }^{21}$. Інколи у творі настільки важко визначити межу між раціональним та ірраціональним, що виникає питання: у якому вимірі розгортаються події, де закінчується реальність і починається сон, як, наприклад, в оповіданнях зі збірки «Сон із дзьоба стрижа».

Серед найпоширеніших видів онейротопів, які вживає письменник у творах. сни-передчуття. Саме в романі «Кохання в стилі бароко», на думку

18 Даниленко Володимир: рівень національної літератури визначають аристократичні проекти. Спецкор. 2008. URL: http://spetskor.dp.ua/ art_767.php.

19 Даниленко В. Сонечко моє, чорне й волохате. Тіні в маєтку Тарновських : повісті. Львів : Піраміда, 2012. С. 7.

${ }^{20}$ Николюк Т. Психологічний портрет творчої особистості у повісті Володимира Даниленка «Сонечко моє, чорне й волохате». Актуальні проблеми української літератури і фольклору : науковий збірник. Донецьк, 2014. Вип. 21-22. С. 28.

${ }^{21}$ Козачук Н. Володимир Даниленко: «Як нерв нації письменник завжди має говорити еліті й народу правду, навіть якщо ії неприємно чути». Слово просвіти. Київ, 2010. № 1 (534). URL: http://slovoprosvity.org/2010/01/12/3030-old/. 
О. Вещикової, онейротопи набувають типу снів-передчуттів. У процесі характеризування їхньої природи дослідниця зазначила, що вони здатні натякнути насамперед читачеві на подальші події у творі: «Реципієнт натикається на передбачення, наявне у сновидінні, налаштовується на містичний настрій, але між його артикуляцією і реалізацією анонсованої події проходить певний час. Як наслідок, утворюється лакуна, невизначеність, що тримає читача в напруженому очікуванні, під час якого увага зосереджується на пошуках зв'язків між фрагментами. При цьому читач отримує задоволення, якщо врешті відбувається реалізація сновидіння, що надає тексту містичного звучання» 22 .

$\mathrm{B}$ онейротопів такого типу основний мотив - це попередження про трагічне завершення життя. Парадоксальність полягає у тому, що людина, яка побачила такий сон, знає про неминучість загибелі, перебуває в його передочікуванні. Цей онейротоп «виконує роль антиципаційного сигналу» ${ }^{23}$ : під час сну людина вже попереджена про майбутню загибель, тобто маємо класичний зразок фаталізму ситуації, коли персонаж знає про смерть, але не може ії відвернути. Інколи герої у В. Даниленка навіть не бажають щось змінити в житті. Так, Валерій Колядевич у снах отримує інформацію про можливу загибель. За допомогою певної символіки, образів-деталей «простежується» у кожному сні семіотика смерті: «Він дивився 3-під стелі на своє порожнє ліжко, тіла він не бачив, йому здавалося, що душа оселилася у бджолі. В кутку спальні висів рій, і він спостерігав за своїм порожнім ліжком крізь очі бджоли. Боявся відриватись від рою, бо за вікном спальні стукав дзьобом у стіну одуд, що міг продовбати дірку і склювати його» ${ }^{24}$. Реципієнт відчуває всі емоції героя, незважаючи на те, що автор жодним чином не подає тлумачення сну. Танатологічні мотиви уві сні перемежовані з еротичними, тому герой перебуває у стані насолоди, коли відчуває момент власної смерті. Тож так звані сни-передчуття стають складовою частиною наративної структури прози автора.

Функціональне призначення сну може стосуватися і здатності примусити людину зробити життєвий вибір, такі онейротопи дістали назву снів-застережень. Якщо говорити про застосування такого типу снів у творах письменника, то найчастіше вони трапляються в тексті, де

22 Вещикова О. Пролептичний потенціал сновидіння у структурі художнього наративу (романи В. Даниленка «Кохання в стилі бароко» i В. Шевчука «Кросворд»). Наукові прачі Чорноморського державного університету імені Петра Могили комплексу «Києво-Могилянська академія». Серія «Філологія. Літературознавство». Миколаїв, 2015. Т. 259. Вип. 247. С. 17.

23 Давиденко І. Міфологічні трансформації в оповіданнях В. Даниленка. Слово i час. 2011. № 9. С. 101.

${ }^{24}$ Даниленко В. Кохання в стилі бароко. Львів : ЛА «Піраміда», 2009. С. 74. 
необхідно попередити героя про небезпеку, якої можна уникнути, якщо звернутися по допомогу до вищих сил або магічних ритуалів. Такі види сну використовує автор у творах «Дегустація у будинку з химерами», «Людина громів», «Розбуди мене до Парипсів» та ініших. Так, в оповіданні «Дегустація у будинку 3 химерами» головний герой, режисер Анатолій Бутенко перед виконанням замовлення щодо організації в будинку 3 химерами театралізованої дегустації вина бачить декілька снів-застережень. Однак, незважаючи на прямий натяк, що йому загрожує смерть, герой погоджується виконати замовлення й отримати великий гонорар. Сни-застереження у творах глибоко символічні, кожен образ, навіяний у маревах сну, несе на собі відбиток смерті: це і наречена в чорній вуалі, і крики воронів. Водночас у сні героя чітко зафіксовано, що він має зробити вибір між життям і смертю, про це рішення, також у завуальованій, прихованій формі режисер отримує попередження від образу світлого чоловіка, який асоціативно пов'язаний із життям.

Це є доказом того, що в оповіданнях В. Даниленка відбувається процес «створення анахронії, вихід за межі законів простору-часу і у зв'язку із цим здатність розкривати майбутнє» ${ }^{25}$. Тобто профетичні сновидіння відіграють суттєву роль у наративній організації тексту автора. Таку ознаку Даниленківського тексту неодноразово відзначали й науковці, наприклад, П. Білоус, який характеризує особливості прийому сну в оповіданні «Сон із дзьоба стрижа», відзначає здатність автора до використання так званої моделі циклічного часу шляхом поєднання реально-побутового «з умовно образним, символічним, трансцендентним, виводить фантасмагоричні картини, які розгортаються через онейротопи» ${ }^{26}$. Натомість Н. Яблонська відзначила ще й таку особливість онейротопів у тексті В. Даниленка, як здатність передбачати, бути віщими, «актуалізуючи «точки дотику» між реальним i фантасмагоричним, співвідносячи певні часові межі iз «пороговим» станом персонажів» ${ }^{27}$.

Ці два типи снів (сни-застереження і сни-передчуття) мають на меті передбачати майбутнє. Їхня внутрішня сутність розкривається у процесі подолання на рівні підсвідомості людиною певного проміжку в часі. Однак існують у тексті В. Даниленка й іншого виду сни, так звані сни-інсайти. Їхня основна роль - розібратися в теперішньому часі.

${ }^{25}$ Руднев В. Культура и сон. Даугава. 1990. № 3. С. 123.

${ }^{26}$ Білоус П. Між першою та останньою чашкою кави. Сон із дзьоба стрижа : оповідання / В. Даниленко. Львів, 2007. С. 6.

27 Яблонська Н. Особливості міфомислення Володимира Даниленка у прозовій збірці «Сон із дзьоба стрижа». Наукові записки. Літературознавство. Тернопіль. № 41. C. 193. 
Наприклад, в одному зі своїх снів Валерій Коляденко («Кохання в стилі бароко») бачить жука, який заповзає до нього у груди, прокушує ребра і живиться його тілом. Водночас герой відчуває байдужість до всього, що з ним відбувається, з'являється відчуття насолоди, незважаючи на передчуття смерті. Сон сниться героєві в момент з'ясування реальних стосунків із коханою Юлією і $є$ наслідком його роздумів про вплив демонічної жінки на його життя. Фантастичні картини і відчуття зі сну сприймаються архітектором як реальна картина - жук зі сну відтворює поведінку іншої істоти - ламехузи, яка шляхом виділення наркотичної речовини в тіло жертви (комахи) одурманює іiі, а потім убиває. Коли мурах знищено, тоді вона вирушає на пошуки інших жертв. Колядевич робить висновок, що таким чином себе позиціонує Юлія, яка примушує архітектора закохатися в неї, тримає його на короткій відстані, змушує виконувати свої бажання. Інтуїтивно герой відчуває парадоксальність ситуації і можливі страшні наслідки такого зв'язку.

Коли відчуває і передбачає свою смерть уві сні, герой ніби стає людиною, яка знає все про світ навколо неї. Це $є$ підтвердженням думки А. Менегетті, що «світ сновидінь - це те нечисленне, що збереглося від початкового природного стану людини, що дозволило їй бути всезнаючою» ${ }^{28}$. Сон стає провідником, який дає повну і чітку картину того, що може відбутися з людиною в реальному житті, однак ця інформація має бути прихованою від ії цілковитого усвідомлення.

Профетичні сновидіння інколи пов'язані із присутністю в них померлих родичів або близьких людей, які можуть певним чином втручатися в живий світ. Знаходимо підтвердження такої позиції і в романі «Кохання в стилі бароко», коли один із героїв, пан Ліберман, веде розмову з Колядевичем про смерть: «Думаєте мертві нічого не бачать? Вони за вами спостерігають, приходять у ваші сни, підказують, коли треба, і переживають, коли ви щось не те робите» ${ }^{29}$.

Окрему групу сновидінь у творах становлять компенсаційні сновидіння. Найчастіше іх автор використовує у творах «Нічний коханець», «Пізня шпанка», «Посмішка Савула», «У промінні згасаючого сонця» 3 метою розкриття психологічного стану персонажів, які перебувають на межі вибору, який окреслює дві протилежні категорії - з одного боку, це ірреальність, мрії, а з іншого реальність буття. Інколи герої уві сні можуть наблизитися до реалізації своєї мрії значно швидше, ніж у реальному житті. Наприклад, Ліза («Посмішка Савула») спочатку реалізовує уві сні мрію побачити

${ }^{28}$ Менегетти А. Образ и бессознательное : учебное пособие по интерпретации образов и сновидений. Пер. с итал. Москва, 2000. С. 19.

${ }^{29}$ Даниленко В. Кохання в стилі бароко. Львів : ЛА «Піраміда», 2009. С. 146. 
«костяний світ мертвого часу» ${ }^{30}$. Савула із скульптури стає героєм, живим чоловіком, сильним та впевненим, він більшою мірою асоціюється із «чоловічистю», аніж опецькуватий i безпорадний чоловік Владислав. В іншому творі «У промінні згасаючого сонця» Костянтином Грубичем оволодіває бажання пізнати сексуальну насолоду з молодою польською красунею XIX ст., у мріях спочатку він такою собі й уявляє свою набагато старшу коханку Кароліну Собанську, після того, як дізнається про ії таємницю. Бажання мати коханку з'являється раптово, він швидко його реалізує, паралельно домріює своє бажання у снах, і лише в перших проміннях вранішнього сонця стає зрозуміло, що в реальному світлі його кохання наповнюється відразою до об'єкта кохання через глибоко поважний вік «Від скісного проміння зморшки були глибокі й рельєфні. Здригнувся і тремкими ніздрями відчув запах старого жіночого тіла, від якого його пересмикнуло $<\ldots>>{ }^{31}$. Схожі моменти можемо побачити і в оповіданні «Пізня шпанка», де нереалізовані бажання Ванди висвітлені у сновидіннях. Глибоко символічні у творі є образи нічних метеликів, які стукають у вікно Віталія, об'єкта еротичних бажань «самотньої жінки із сусіднього будинку» ${ }^{32}$. Для Ванди як заміжньої жінки вони є свідченням потаємних прагнень, бажанням мати коханця, а отже, мати гріх. Це свідчення прощання героїні з молодістю, з вільним часом, коли вона мала змогу зустрічатися із чоловіками, їх обирати та віддаватися з усією пристрастю.

Цей мотив втрати часу $\mathrm{i}$ жіночих можливостей інколи в ірреальному світі постає замасковано. Наприклад, в оповіданні «Нічний коханець» Люба в реальному житті стала свідком згвалтування старшої сестри і втратила здатність сприймати тілесність чоловіків, вони стали для неї втіленням жорстокості та грубості: «I коли згодом ii подруги захоплювались хлопцями, Люба усамітнювалась і тікала у книжки <...> Вона не пережила традиційного для дівчат періоду закоханості ні у школі, ні в університеті < ..> Їй подобалось спілкуватись із розумними старшими чоловіками, але як тільки відчувала, що вони хочуть від неї більше, віддалялася, посилаючись на зайнятість» ${ }^{33}$.

${ }^{30}$ Даниленко В. Сон із дзьоба стрижа : оповідання. Львів : ЛА «Піраміда», 2006. С. 84.

31 Даниленко В. Сон із дзьоба стрижа : оповідання. Львів : ЛА «Піраміда», 2006. С. 282.

32 Даниленко В. Сон із дзьоба стрижа : оповідання. Львів : ЛА «Піраміда», 2006. С. 96-97.

33 Даниленко В. Сон із дзьоба стрижа : оповідання. Львів : ЛА «Піраміда», 2006. С. 117. 
До комплексу старої діви героїня не доростає, адже усвідомлює, що із часом із іiі психікою можуть статися зміни і вона не бажатиме одруження. Однак підсвідома настанова на «одинокість» не дає змоги жити повноцінним життям - одруження ії численні, вони не тривкі за часом, призводять до все більшого розчарування в чоловіках. Із часом іiї підсвідомі бажання мати ідеального коханця міцніють і втілюються у психічних станах, близьких до сну, - видіннях, галюцинаціях і мареннях: «<...> Відчула крізь сон, як увігнулося ліжко й біля неї хтось ліг, і тоді чиїсь пальці торкнулись стегна й завмерли, а потім обережно поповзли вище» ${ }^{34}$.

Завдяки вживанню стану на півсвідомості, вправному переданню відчуттів героїв В. Даниленкові вдається стерти межу між реальним світом та ірреальністю, важко інколи зрозуміти, на якому етапі ця грань зникає: «Це не сон, <..> я відчувала його фізично», - пояснює свій стан на півсвідомості героїня Люба Джус своїй подрузі, водночас зауважує: «Навіть якщо це приснилось, як ти поясниш, що він приходив до мене на роботу?» ${ }^{35}$. Якщо ж звернутися до позатекстового матеріалу, то ще сюрреалісти відзначали, що такий стан, описаний героїнею, передбачає: «розум, доходячи до межі підсвідомого, перестає розпізнавати, де він перебуває», оскільки в ньому народжуються «образи, які починають втілюватися у плоть і кров», тобто ці образи стають матерією життя ${ }^{36}$.

Що ж до тексту твору, то варто простежити поступові зміни стирання граней раціо й ірреальності. У стані напівсну героїня спочатку чує кроки, скрип підлоги, шурхіт і вгинання ліжка, як ії чужі пальці починають пестити. Із часом звуковий ефект посилюється, відбувається матеріалізація ii коханця вночі, а надалі і вдень, він якимось чином потрапляє в ії сприйнятті на роботу: «Люба відчула, що незнайомець, якого вона чекає, вже тут $<\ldots>$ він затулив долонею їй очі, поклав жінку на стіл, припав до грудей, легкий і гарячий, мов літній вітер» ${ }^{37}$. Епізод із дзеркалом стає у творі відправними моментом переходу реальності у світ зміненої свідомості, ірреальний світ. Оголена героїня розглядає себе у дзеркалі і відчуває чиюсь присутність,

${ }^{34}$ Даниленко В. Сон із дзьоба стрижа : оповідання. Львів : ЛА «Піраміда», 2006. С. 119.

35 Даниленко В. Сон із дзьоба стрижа : оповідання. Львів : ЛА «Піраміда», 2006. С. 123.

36 Омельчук Ю. Сюрреалістичні особливості новели В. Даниленка «Сон із дзьоба стрижа». Філологічні трактати : науковий журнал. Суми, 2013. Т. 5. № 1 . С. 50 .

37 Даниленко В. Сон із дзьоба стрижа : оповідання. Львів : ЛА «Піраміда», 2006. С. 121. 
однак від того, що хтось займається вуаєризмом, вона збуджується. Ця сцена $\epsilon$ алюзією на епізод із твору В. Шевчука «Дім на горі»: «Галя $<\ldots>$ мала почуття, наче стоїть роздягнута, а крізь вікно незмигно дивляться чоловічі очі. Охала, аж затуляла рота долонею, а другу долоню впускала до лона» ${ }^{38}$.

У творах В. Даниленка інколи дуже важко визначити, який вид сну $\epsilon$ провідним, психічні стани та їхні вияви поєднуються й утворюють свій світ. Так, у «Розбуди мене до Парипсів» змальовані такі види станів, як сни-бажання, сни-мрії, сни-застереження та сни-хвороби. Також усе починається в героїні із сексуального насильства, яке сталося в дитинстві. Глибока психологічна травма призводить до розвитку зміненої свідомості, яка виражається в Софії у вигляді гіперсомнії. Ця хвороба проявлялась у неї у вигляді постійного бажання спати: «Як тільки сутеніло, вона засинала і могла проспати до обіду. Прокинувшись, кілька годин відходила від сну, пила каву, в неї боліла голова, була роздратованою і сонною» ${ }^{39}$. Стан активної праці в жінки тривав недовго - лише чотири години, після яких вона знову впадала в напівсвідомий стан: «<... I як тільки сідала чи притулялася до стіни, відразу засинала. Тоді ії не можна було чіпати, шарпати, роздягати, чіплятися з розмовами чи ласками» ${ }^{40}$. Уві сні героїня була «схована» від проблем реального буття, зокрема й від реальних стосунків із чоловіками.

Однак паралельно у свідомості героїні виникали картини ірреального світу, їй було важко відрізнити - це наслідок ії творчої уяви чи відбувалося це насправді. Такий стан зміненої свідомості, поява галюцинацій і бажання мати ці галюцинації $є$ основними ознаками гіперсомнії. У цьому творі також, як і в Люби 3 «Нічного коханця», iii бажання постають у вигляді снів, сповнених таємних еротичних потягів. Уява героїні «домальовує» дійсність, доки вона може спати. Так, Софія знаходить собі насолоду, «переглядаючи» еротичні видива на педраді з Ярославом, у тролейбусі зі злодієм, у Михайлівській церкві зі священиком. Досить промовистою характеристикою межового стану героїні $\epsilon$ сцена, де вона уявляє, як її у тролейбусі грабує злодій, водночас вона отримує сексуальне задоволення, коли чиїсь обережні руки «прослизають у кишеню іiі плаща, торкаються стегна, їй приємно, вона знає, що це кишеньковий злодій, тулиться спиною до нього, відчуває тепле тверде тіло. Його

38 Шевчук В. Дім на горі. Київ : А-БА-БА-ГА-ЛА-МА-ГА, 2013. URL: https://coollib.com/b/304343.

39 Даниленко В. Сон із дзьоба стрижа : оповідання. Львів : ЛА «Піраміда», 2006. C. 53.

${ }^{40}$ Даниленко В. Сон із дзьоба стрижа : оповідання. Львів : ЛА «Піраміда», 2006. C. 53. 
чутлива й волохата рука обережно, прослизає в пазуху, мацає великі затверділі груди, шукає гаманця. «Отут, отут $<\ldots>$ », - шепоче вона» ${ }^{41}$. Однак бачити еротичні сни не означає реалізовувати їх насправді. Сімейне життя не має такого еротичного нашарування, здатності відчувати задоволення. Софія прагне залишитися 3 нереальним чоловіком, зі снів, підсвідомо бажає смерті своєму реальному чоловікові. Проте шлях до мрії реалізувати нічні видива обертається для неї сном-застереженням, у якому ірреальний коханець обіцяє: «Я заберу тебе до себе, <..> коли помре твій чоловік» ${ }^{42}$. Водночас автор подає в тексті картину ще одного сну, яку можна позначити як мрію героїні: уві снах вона їде до батьків у Парипси. Поряд із нею іiі коханий Ярослав, а вона одягнена у весільну сукню. Різні сни застереження і мрія «зіштовхують» в одну площину два психічні стани героїні - страх перед смертю і відчуття щастя. Героїня постійно перебуває на межі між цими станами, однак має зробити вибір занедбує шлюбні обов'язки, приділяє увагу коханцеві, наче прагне постійно відчувати почуття задоволення. Однак сон-застереження в iii житті здійснюється - вона гине в автокатастрофі. Такий сонзастереження, який перетворюється на реальність, отримують й інші герої у творах В. Даниленка. Так, у «Поцілунку Анжели» головний герой «залишається уві сні», помирає в реальному житті: «Я задрімав, коли за вікном хтось погукав - раз і вдруге, і втретє. Я сидів за столом зі складеними руками й заплющеними очима і бачив Марисю, Гуцуляка, Гогулю, Ромцю Хилюка. Я простягнув їм руки, ступив у вікно, і ми пішли залитою світлом нічною вулицею» ${ }^{43}$.

Окрему групу онейротопів становлять сни-забуття. Ця категорія снів передбачає намагання людини «заховатися» від реальних проблем у світі ірреальному. Сон стає такою можливістю, у своїй ірреальності він нагадує смерть, він $є$ своєрідною «втечею із власного простору» (Е. Фромм) тоді, коли в житті людини немає сенсу. Використання снівзабуття в текстах В. Даниленка реалізовується в оповіданні «Черемхова віхола». Головна героїня Юлія хвора, бажання боротися із хворобою вона не має, а отже, не має й бажання повертатися до того часу, коли не була хворою, вона втратила інтерес до реального світу, адже «ні диплом юриста, що його мала одержати, ні хлопці, яким подобалася,

41 Даниленко В. Сон із дзьоба стрижа : оповідання. Львів : ЛА «Піраміда», 2006. С. 55.

42 Даниленко В. Сон із дзьоба стрижа : оповідання. Львів : ЛА «Піраміда», 2006. С. 56.

43 Даниленко В. Сон із дзьоба стрижа : оповідання. Львів : ЛА «Піраміда», 2006. С. 200-201. 
не викликали в неї захоплення» ${ }^{44}$. Юлія стає байдужою до інтересів своїх ровесників, а хворобу сприймає як засіб «сховку» від світу. Цю думку підтверджують дослідження Й. Брейера та 3. Фройда про те, що психічний та емоційний стан людини може викликати різні соматичні розлади і здатний вплинути й на ії фізичний стан. Емоційний стан героїні твору зосереджений навколо розпачу та суму, які призводять іiі до парасомнії, зміненого стану свідомості, коли людина весь час квола і спить, шукає полегшення в забутті. Лікар пропонує батькові хворої реалізувати сни-фантазії дівчини, бо «вона має когось любити $<\ldots>$ або у щось вірити, хоча б у сни. Інакше помре» ${ }^{45}$. Для здійснення сну наймають актора, створюється відповідна атмосфера зимового саду, однак покращення здоров'я Юлі тимчасове - до того часу, поки вона не дізнається про правду. Реальність призводить до смерті дівчини: «Тату, тату, <..> ти можеш купувати дорогі автомобілі і найняти актора Сашу, але навіть ти не зможеш відкупити мене від смерті» ${ }^{46}$.

Ще один із видів онейротопів - сон як результат психічного захисту, застосований в оповіданні «Сон із дзьоба стрижа». Батьки в реальному житті поховали доньку. Саме сон дає змогу зменшити психологічний тиск на їхню свідомість. Після смерті доньки батьки Лесі, емоційно прибиті i знервовані, знаходять заспокоєння в догляданні за пташеням. Коли воно прожило певну кількість часу в них, вони припиняють багато говорити по смерть доньки, а на ii сороковини загибелі мати сприймає факт іiї смерті як данність: «її очі були зажурені, та в них вже світилося життя» ${ }^{47}$. Після чергового сну батько прокидається і випадково чує знову страшне повідомлення про доньку, яку «знайшли вбитою недалеко від кабаре», однак цей факт він сприймається більш-менш спокійно, він навіть вирішує не будити жінку: «Хай поспить трохи, доки скажу їй те, що мушу сказати» ${ }^{48}$.

Отже, герої В. Даниленка часто перебувають на межі сну й реальності, між реальним та фантастичним світами. Іноді ці світи накладаються один на одного, утворюють містичну дійсність. Такі особливості прози митця

44 Даниленко В. Сон із дзьоба стрижа : оповідання. Львів : ЛА «Піраміда», 2006. С. 33.

45 Даниленко В. Сон із дзьоба стрижа : оповідання. Львів : ЛА «Піраміда», 2006. С. 29.

46 Даниленко В. Сон із дзьоба стрижа : оповідання. Львів : ЛА «Піраміда», 2006. С. 40.

47 Даниленко В. Сон із дзьоба стрижа : оповідання. Львів : ЛА «Піраміда», 2006. С. 24.

48 Даниленко В. Сон із дзьоба стрижа : оповідання. Львів : ЛА «Піраміда», 2006. С. 28. 
дають підстави відзначити тяжіння автора до сюрреалізму, якому властива посилена увага до підсвідомого та сновидінь.

\section{ВИСНОВКИ}

Сон і сновидіння в художньому тексті В. Даниленка стають повноцінною складовою частиною сюжетно-композиційної будови, провідною особливістю його індивідуального стилю. За використанням «онейротопів» він стає найбільш впізнаваним письменником. Онейротропи у прозі використані як засоби надання психологічної характеристики героя, розуміння його внутрішнього емоційного стану. Сюрреалістичне тяжіння до явищ підсвідомого, «завуальована» реальність, балансування свідомості літературного героя на межі реального й ірреального світів формують наративну стратегію прозової творчості митця. Серед індивідуальних особливостей - сприйняття онейротопу як художньої деталі, на якій тримається сюжет або приховане ідейне навантаження твору. Звідси - кількарівневість тексту В. Даниленка, із широким діапазоном підтексту, повне дешифрування якого неможливе, автор може й не усвідомлювати повною мірою езотеричної значущості творів.

Онейричний простір В. Даниленка - сни-передчуття, снизастереження та сни-інсайти, які спрямовані на майбутнє, також широко вживані в тексті так звані компенсаційні сни (сон як мрія, потаємне бажання), сни-забуття та сни як результат психічного захисту. Сни стають перехідним станом свідомості між світами живих і мертвих, а потойбічні сили здатні спілкуватися із живими і передавати їм необхідну або таємну інформацію.

\section{АНОТАЦІЯ}

У статті означено широке коло питань, пов'язаних із функціонуванням проблеми сну і сновидінь у художній літературі. На прикладі літературної творчості сучасного українського письменника Володимира Даниленка розкрито питання співвідношення сну і сновидінь у художньому тексті, охарактеризовано різні види онейротопів, наголошено, що їх уживання $\epsilon$ провідною рисою індивідуального стилю митця. Відзначено, що персонажі у творах перебувають на межі сну й реальності, які утворюють містичну дійсність. 3 урахуванням таких ознак прози В. Даниленка підкреслимо наявність рис сюрреалізму 3 характерною увагою до підсвідомого та сновидінь. Під час проведеного художнього аналізу творів письменника зроблено систематизацію складових частин онейричного простору (сни-передчуття, сни-застереження та сни-інсайти, які 
спрямовані на майбутнє; компенсаційні сни (сон як мрія, потаємне бажання); сни-забуття; сни як результат психічного захисту).

\section{ЛІТЕРАТУРА}

1. Бовсунівська Т. Достовірність онірокритики та іï постмодерні стратегії. Сучасні літературознавчі студї : збірник наукових праць. Київ, 2004. Вип I : Онірична парадигма світової літератури. С. 14-22.

2. Вещикова О. Пролептичний потенціал сновидіння у структурі художнього наративу (романи В. Даниленка «Кохання в стилі бароко» i В. Шевчука «Кросворд»). Наукові праиі Чорноморського державного університету імені Петра Могили комплексу «Києво-Могилянська академія». Серія «Філологія. Літературознавство». Миколаїв, 2015. Т. 259. Вип. 247. С. 14-18.

3. Вещикова О. Семіотика містичного в оповіданні В. Даниленка «Дегустація в будинку з химерами». Сучасна україністика. Проблеми мови, літератури та культури. Оломоуць, 2014. С. 270-273.

4. Волик Е. Язык и функции сновидений в словесном искусстве. Вісник Харківської державної академії дизайну і мистеитвв. Серія «Мистецтвознавство. Архітектура». 2007. № 3. С. 160-164.

5. Володимир Даниленко: рівень національної літератури визначають аристократичні проекти. Спецякор. 2008. URL: http://spetskor.dp.ua/ art_767.php.

6. Давиденко I. Міфологічні трансформації в оповіданнях В. Даниленка. Слово і час. 2011. № 9. С. 100-106.

7. Даниленко В. Кохання в стилі бароко. Львів : ЛА «Піраміда», 2009. $300 \mathrm{c}$.

8. Даниленко В. Сон із дзьоба стрижа : оповідання. Львів : ЛА «Піраміда», 2006. 384 с.

9. Даниленко В. Сонечко моє, чорне й волохате. Тіні в маєтку Тарновських : повісті. Львів : Піраміда, 2012. С. 5-80.

10. Даниленко В. Тіні в маєтку Тарновських : повісті. Львів : Піраміда, 2012. 180 с.

11. Козачук Н. Володимир Даниленко: «Як нерв нації письменник завжди має говорити еліті й народу правду, навіть якщо ії неприємно чути». Слово просвіти. 2010. № 1 (534). URL: http://slovoprosvity.org/ 2010/01/12/3030-old/.

12. Кононенко Є. Володимир Даниленко і література 3 пробірки. URL: http://www.umoloda.kiev.ua/number /810/164/29496/.

13. Лаврусенко М. Жанрово-стильові особливості оповідання Володимира Даниленка «Черемхова віхола». Вісник Луганського національного університету. 2012. № 3. Ч. ІІ. С. 171-177.

14. Літературознавча енциклопедія : у 2-х т. / авт.-укл. Ю. Ковалів. Київ : ВЦ «Академія», 2007. Т. 2. 643 с. 
15. Николюк T. Ірраціональне у прозі Володимира Даниленка Актуальні проблеми украӥнської літератури і фольклору. 2013. № 23. C. 23-28.

16. Николюк Т. Психологічний портрет творчої особистості у повісті Володимира Даниленка «Сонечко моє, чорне й волохате». Актуальні проблеми української літератури $і$ фольклору : науковий збірник. 2014. Вип. 21-22. С. 27 - 34.

17. Омельчук Ю. Сюрреалістичні особливості новели В. Даниленка «Сон із дзьоба стрижа». Філологічні трактати. 2013. Т. 5. № 1. C. $50-54$.

18. Руднев В. Культура и сон. Даугава. 1990. № 3. С. 121-124.

19. Савельева В. Художественная гиппология и оннейропоэтика русских писателей : монография. Алма-Ата, 2013. 320 с.

20. Святе Письмо Старого та Нового завіту. Повний переклад, здійснений за оригінальними єврейськими, арамійськими та грецькими текстами. URL: https://bible-lessons.in.ua/bible/old/book01/gl02.html.

21. Теперик Т. О поэтике литературных сновидений. Русская словесность. 2007. № 3. С. 12-16.

22. Фазиулина И. Сон и сновидение в раннем творчестве Ф.М. Достоевского : поэтика и онтология : дис. ... канд. филол. наук: 10.01.01. Ижевск, 2005. $157 \mathrm{c.}$

23. Фенько Н. Естетичні функції картин сновидінь у художніх творах українських письменників другої половини XIX-XX ст. : автореф. дис. ... канд. філ. наук: 10.01.01. Дніпропетровськ, 1999. 19 с.

24. Фрейд 3. Введение в психоанализ : лекции. Санкт-Петербург, 1999. URL: http://krotov.info/library/21_f/re/freyd_2.html.

25. Шевчук В. Дім на горі. Київ : А-БА-БА-ГА-ЛА-МА-ГА, 2013. URL: https://coollib.com/b/304343.

\section{Information about the authors: Osmak N. D.,}

Candidate of Philological Sciences, Professor, Professor at the Department of Ukrainian Literature National Pedagogical Dragomanov University 9, Pirohova str., Kyiv, 02000, Ukraine

Bykova T. V.,

Doctor of Philology, Associate Professor, Professor at the Department of Ukrainian Literature National Pedagogical Dragomanov University 9, Pirohova str., Kyiv, 02000, Ukraine 